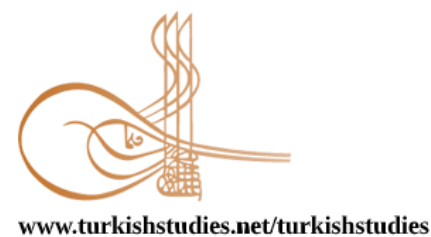

Turkish Studies

\title{
Film Okuryazarlığı: Sosyolojik Açıdan Kız Kardeşler’i Okumak
}

\author{
Film Literacy: Reading A Tale of Three Sisters Sociologically
}

\author{
Seher Şeylan*
}

\begin{abstract}
With the developing technology, today's century requires the individual, who is under the bombardment of information from all sides, to have some literacy skills in order to reach the correct information. It is essential to be a media literate in order to be aware of the social, cultural and political messages that lie behind the abstract, concrete, sound and movement messages from the media, which are often primary source of information. On the other hand, although the ability to read the media can be sufficient at the point of analyzing traditional and new media messages, understanding the implicit language of the movies whose domain is expanding today and having the ability to criticize the film is called film literacy. Film literacy, which aims to create an audience that has the qualities of understanding and evaluating cinematic products rather than watching films passively, reaches the layers of meaning lying in the depths of the film and considers the film as a product of culture and art rather than seeing it as a tool to spend time watching. Sociological analysis, which is one of the methods of film reading, reads films as a social art and cultural product. In other words, this method sees movies as a cultural product that reflects the values and ideals of society. On the basis of reading films with a sociological understanding, it is aimed to determine society's value judgments, social memory, lifestyle and social roles within the framework of nation, class, race and gender. In this type of reading, films refer to the social data of the period in which they were produced or the period they deal with. In this study Three Sisters (Emin Alper, 2019) will be analyzed from a sociological perspective in the context of class, gender, act, role and potency. When the film is analyzed with sociological reading, it is concluded that it contains data in the context of class struggle, gender, roles and power.
\end{abstract}

Structured Abstract: Literacy ability, which is based on making sense of what seen and heard on the screen and the silver screen, expands the field of meaning with new concepts such as media literacy, visual literacy etc. Literacy enables us to make sense of the world live in. Human being makes sense of the world we exist in through our memory full of stories. Stories hosted by memories full of our experiences and knowledge sometimes reach us through a film. Cinema is undoubtedly one of the ways to understand better and make sense of world.

The purpose of a film is not just to entertain the audience by distracting them from social problems. The film brings together fictional lives and real lives. Thus, it includes real-life stories, characters and problems in the fictional World by bringing the past, present and future together on the big screen. The individual, who witnesses the lives which does not know about, manages to empathize with them, through

*Dr. Öğr. Üyesi, FMV Işık Üniversitesi, Sanat Tasarım ve Mimarlık Fakültesi, Sinema ve Televizyon Bölümü Asst. Prof. Dr. FMV Isik University, Art Design and Arthitecture Faculty, Cinema and TV Department ORCID /0000-0001-9477-5744

seylanseher@gmail.com

Cite as/ Atıf: Şeylan, S. (2021). Film okuryazarlığı: Sosyolojik açıdan Kız Kardeşler’i okumak. Turkish Studies, 16(6), 1749-1761. https://dx.doi.org/10.7827/TurkishStudies.52326

Received/Geliş: 12 August/Ağustos 2021

Accepted/Kabul: 25 December/Aralık 2021

Checked by plagiarism software

Published/Yayın: 30 December/Aralık 2021

CC BY-NC 4.0 
the film. So the audience increases ability to interact with the world live in by watching the film. For this reason, it is very important to make sense of the watched film. Film literacy called the way of understanding and perceiving cinema, first looks at its relationship with reality while reading any film. The movie, which shows the events in a different way than in real life, allows the audience to see the events from different perspectives and in a different way. It is very natural for the cinema, which has different storytelling methods, to have more than one analysing methods. At this point, cinema as a phenomenon to be understood and perceived; raises many problems that need to be examined for aesthetics, audience sociology, theory and semiotics.

In this study, Three Sisters (Emin Alper, 2019) will be analyzed sociologically in the context of class, gender, role and power.

The approach, which considers the criticism of films within a framework based on social sciences according to sociological criteria, evaluates films as a product of social art and culture. In this respect, the film is examined in the context of the social conditions of the period in which it was produced or the period it deals with. From this point of view, no matter what genre or historical period a movie belongs to, it is considered as a document that provides social data. On the basis of this understanding, sociological criticism analyzes films on the axis of concepts such as class, race, gender and nation. Who reads a film with a sociological approach in the light of these concepts, considers films as a cultural product that reflects society's values, rules, ideals and worldview. Being able to make sociological film analysis makes it necessary to better understand both the social structure and the films, to establish a connection between the films in question and society and the culture.

In the film, Three Sisters (Alper, 2019) which tells the struggle for existence of three sisters, reveals the class distinctions, gender problems, role and power struggle in the society the story takes place. The concept of class can basically be defined as a group of people who have some things in common. The difference between classes arises from the difference of social classes in different education, status, income, job, profession and life styles. On the other hand, all relations between gender roles are essentially a struggle for power. The gender order between men and women is the pattern of power and power relations established between the definition of femininity and masculinity from past to present.

In the film Three Sisters (Alper, 2019), the director conveys the story of three sisters, who are stuck in the axis of class conflicts, power and genderism, in a sociological way with observations from their own past. Although it seems all the decisions about the future lives of the women taken by men of the film, it is not only women who struggle by being stuck in the realm of class conflicts, power and gender in the film. The possessor of has power not only over women, but also over men of the lower class. It is seen that the power, which is the decision maker, is the only salvation option for both women and men.

One of the ways of making sense of the stories that cinema tells in this context, which functions to convey the basic characteristics, lifestyle and point of view of a society, is to analyze the film from a sociological point of view.

Keywords: Film literacy, gender, class, potency, sociological analysis

Öz: Günümüz yüzyılında gelişen teknoloji ile beraber dört bir taraftan bilgi bombardımanı altında kalan bireyin, doğru bilgiye ulaşması için bir takım okuma yazma becerilerine sahip olmasını gerekmektedir. Çoğu zaman birincil bilgilenme kaynağı olan medyadan soyut, somut, ses ve hareket aracılığıyla bireye ulaşan iletilerin ardında yatan toplumsal, kültürel ve politik mesajların farkına varabilmek için medya okuryazarı olmak şarttır. Öte yandan, medyayı okuma becerisi geleneksel ve yeni medya iletilerini çözümleyebilme noktasında yeterli olabilmekle beraber, günümüzde etki alanı gittikçe genişleyen sinema filmlerinin örtük dilini anlamak ve filmi eleştirebilme becerisine sahip olmak film okuryazarlığı olarak adlandırılmaktadır. Filmleri edilgen bir şekilde seyretmekten öte, anlama ve değerlendirme niteliklerine sahip bir seyirci kitlesi yaratmayı hedef edinen film okuryazarlığı, filmin derinliklerinde yatan anlam katmanlarına ulaşır. Bu yaklaşım, film seyretmeyi vakit geçirmek için bir araç olarak görmek yerine, filmi kültür ve sanat ürünü olarak değerlendirir. Sosyolojik analiz filmleri sosyal bir sanat ve kültür ürünü olarak okuyan yöntemlerden biridir. Bu yöntem filmleri toplumun değer yargılarını ve ideallerini yansıtan kültürel birer ürün olarak görür. Filmleri sosyolojik anlayışla okumanın temelinde ulus, sınıf, ırk, cinsiyet çerçevesinde toplumun değer yargılarını, toplumsal hafızasını, yaşam biçimini, toplumsal rolleri saptamak hedeflenir. Bu tür okumada, 
filmler üretilmiş oldukları ya da ele aldıkları dönemin toplumsal verilerine göndermede bulunur. $\mathrm{Bu}$ çalışmada Kız Kardeşler filmi (Emin Alper, 2019), sınıf, iktidar, toplumsal cinsiyet ve roller bağlamında sosyolojik açıdan analiz edilmektedir. Sosyolojik okuma ile analiz edilen filmin sınıf mücadelesi, toplumsal cinsiyet, roller ve iktidar bağlamında veriler barındırdığı görülmektedir.

Anahtar Kelimeler: Film okuryazarlığı, toplumsal cinsiyet, sınıf, iktidar, sosyolojik analiz

\section{Giriș}

İçinde bulunduğumuz yüzyılda çoğunlukla aralarındaki fark gözetilmeden birbirlerinin yerine kullanılan okuma-yazma ve okuryazar kavramları arasındaki anlam farkı giderek daha çok açılmaktadır. Bir tarafta harfleri çözümlemeye dayanan okur-yazar olma yetisi diğer tarafta ekranda ve beyaz perdede gördügünü ve duyduğunu anlamlandırmaya dayanan okuryazarlık yetisi her geçen gün medya okuryazarlığı, görsel okuryazarlık vb. gibi yeni kavramlarla bir araya gelerek anlam sahasını genişletmektedir (Kurudayığlu \& Tüzel, 2010, s. 285). Bu noktada medyayı okuyabilme yetisi görsel mesajların oluşturulmasında ve aktarılmasındaki kültürel, ekonomik, politik ve teknolojik sınırlılıkların farkındalığı olarak tanımlanabilir (Lewis \& Jhally, 1998, s. 110). Görsel iletilere ilişkin bu farkındalık bir filmi yapısal ve içeriksel olarak çözümlemek için de gereklidir.

Dünyanın bir iz düşümü olan her film, dünyanın değişmez dengesini, diğer taraftan bir oyun ve eğlence oluşunu seyirciye aktarmanın bir yoludur. Dünya bir oyun sahnesi iken, yönetmen ilahi güce sahip bir tasarımcidır, insanlar oyuncu, kader senaryo metni, replikler ise insanların hayatlarındaki eylemleridir. Tüm bu özelliklere sahip ve içinde yaşadığımız dünyayı algılama ve anlamlandırmanın en önemli araçlarından biri olan yedinci sanat sinema, varlıkla ilgili sorulabilecek tüm sorular için geniş bir alan açarken, bunu varoluşsal bir dil sunarak gerçekleştirir (Yalsızuçanlar, 2008, s. 9-10). Diğer bir deyişle, film hiçbir zaman seyirciyi toplumsal sorunlardan uzaklaştırarak yalnızca eğlendirmeyi hedef edinmez. Film bugünü, geçmişi ya da geleceği, gerçeği aynı zamanda gerçek olmayanı bununla birlikte rüyayı ve gerçek hayatı aynı ortak rüyayı aynı ortak bilişsel düzlemde yeniden birleştirir. Dolayısıyla kurmaca anlatı içinde sinemanın en önemli başarısı, senaryo ekseninde gerçekliği ve gerçek yaşamı tekrar yaratırken, öte yandan seyirciye, gerçekliğin kendisinin kurmaca tarafını fark ettirmesidir. Film seyretmek, insanın içinde bulunduğu dünya ile etkileşim kurma becerisini artırır. Çünkü birey, seyrettiği bir filmle tanımadığı hayatlara tanık olmayı, o hayatları yaşayanlarla empati kurmayı başarır (Diken \& Laustsen, 2010, s. 15-28).

Ucu bucağı olmayan bir alan olan sinemanın birden çok giriş kapısına sahip olması çok doğaldır. Bu noktada, anlamlandırılacak ve algılanacak bir olgu olarak sinema; estetik, seyirci sosyolojisi ve göstergebilime yönelik incelenmesi gereken pek çok sorun ortaya çıkarır. Bilimsel açıdan incelenebilecek sinemaya ilişkin söylenebilecek pek çok söz vardır (Metz, 2012, s.19). Film okuryazarlığı olarak adlandırılan sinemayı anlama ve algılama biçimi, herhangi bir filmi okurken öncelikle onun gerçeklikle ilişkisine bakar. Olayları gerçek yaşamda olduğundan farklı bir şekilde gösteren sinema filmi, seyircinin olayları farklı bakış açılarıyla ve değişik bir biçimde görmesini sağlar. Beyaz perdede hayatın doğal akışından farklı biçimde görülen, duyulan ve hissedilen görüntüler, seyircinin olay hakkında farklı düşünmesini sağlarken olaya ilişkin mevcut düşünce ve yargıların değiştirilmesinin önünü açar (Büker, 2012, s. 4). Diğer bir deyişle, her film yarattığı evren ile farklı bakış açıları ortaya koyar ve seyircinin daha önce görmediğini görmesini, duymadığını duymasını ve hissetmediğini hissetmesinin önünü açar. Bu yönüyle film gerçekte bilineni kendine özgü bir anlatı tarzı ile ortaya çıkarır. Dahası filmin anlattıkları gerçek dünya ile doğrudan bağlantılı olduğu için, film bilindik olanı bilindik şeklide aktarmak yerine olayları farklı bir yaklaşımla anlamlandırmayı seçer (Tuncel, 2016, s. 327). Bu noktada filmi anlamlandırma, filmden bir anlam çıkarma eylemlerinin toplamında filmi okuyan kişi hiç kuşkusuz seyircidir. Seyirci, sinemanın önemli varlık nedenlerinden biridir. Seyirci bir filmin "bakanı"dır, "göreni" dir 
ve bu yönüyle bir filmin film olduğunun tanığıdır (Kırel, 2010, s. 14). Bir filme tanık olmak adına "bakan' olmaktan öte "gören" olması gereken seyircinin film okuryazarlı̆̆1 düzeyi önemli rol oynar.

\section{Film Okuryazarlı̆ğ}

Her sanat eseri konuşur, onu görene, ona dokunana, onu duyana, onu hissedene kendisini anlatır. Şair okurlarına kelimelerle seslenir, ressam yalnızlığının acısını renklerin tonuna saklar ve fırça darbeleri ile anlatır. Heykeltıraş taşlara saklar 1stırabın derinliğini, suskunluğu. Öte yandan, sinemanın bir sanat dalı ve filmlerin sanat eseri olarak kabul edilmesi ise zaman almıștır. Kamera açılarının bir hikaye yaratmak için bilinçli kullanımı, aydınlatmanın sahnede verilmek istenen duyguya katkısı gibi görsel anlatı bileşenlerinin bir hikayeyi anlatma ya da bir gerçekliği aktarma amaçlı kullanılmasının bir dil oluşturduğunun anlaşılması ile sinemanın bir sanat dalı olarak kabul edilmesinin önü açılmıştır (Ünal, 2010, s. 11). Diğer yandan sinema filmlerinin sadece bir gösteri olmaktan öte bizim dışımızda olup biten ve tanık olduğumuz görsel ağırlıklı her olayı aktaran ve açık ya da örtük mesajlar barındıran, aktarmak istediği düşünceye göre mekansal ve zamansal bir evren yaratma, her şeyi gösterip anlatabilme gücüne sahip olduğu (Metz, 2021, s. 171-174) kabul edilmiştir. Bu yönüyle yönetmen söylemek istediği ne varsa film aracılığı ile söyleme olanağına sahiptir.

Fellini'ye göre sinema hayatı anlatmanın kutsal bir biçimidir ve yönetmenin işi herkesin tanıdığı bildiği içinde yaşadığımız, soluk aldığımız dünyaya çok benzeyen bir o kadar da bilinmeyen tanınmayan dünyalar yaratmaktır. Bir sinema filminin amacı insanla, hayatla derin ve sağlam bir bağ kurmak böylece, hayatı anlamak ve beyaz perdeye aktarmaksa, seyircinin bu filmden edineceği bilgi de insanla, yaşamla, insanın yaşamı yorumlayışı ile ilgili olmalıdır. Ancak burada sözü edilen filmler ticari kar elde etmek üzere çekilmiş gişe filmlerinin aksine felsefi eleştiriye açık, görünenin ötesini aktarmayı hedef edinen, seyirciyi durup düşünmeye sevk eden filmlerdir. Bu filmler insanı yepyeni bir dünya ile karşılaştırmayı başaran, hep alıştığı, çok iyi bildiğini sandığı şeyleri bambaşka bir açıdan görmesini sağlayan, gerçeğin daha kapsayıcı, çok daha geniş bir bakışla görülmesinin önünü açan, felsefi değerlendirmeye açık filmlerdir. Felsefe ya da düşünce ile buluşarak, görünen ve bilinen algının sınırlarının ötesine geçen sinema sanatı, insana heyecan ve haz vermenin ötesinde aydınlanmış bir bilincin yolunu açar (Savaş, 2008, s. 23-28). Bu bağlamda, bilincin sinema yolu ile aydınlanması ise film okuryazarlığı yetisi ile mümkündür. Film okuryazarlığı kavramını ilk kez kullanan, Batı Afrika'da uzun yıllar eğitmenlik yapan John Wilson (1961)'dır.Wilson, filmleri eğitim amaçlı kullanmaya çalışırken daha önce hiç film görmemiş Afrikalıların tanıdık oldukları nesnelerin görüntülerini dahi iki boyutlu anlamsız şekiller olarak yorumladıklarını aktarır. Afrikalı seyirciler Wilson'ın gösterdiği sivrisineklerin çoğalmasının nasıl engellenebileceğini konu alan bir filmde sadece bir tavuk gördüklerini söylemişlerdir. Wilson ve ekibi filmi tekrar seyrettiklerinde filmin bir yerinde anlatıyla hiç ilgisi olmayan bir tavuğun ekranın ortasından değil köşesinden geçtiğini görmüşlerdir. Filme ilişkin başka sorular sorulan seyirciler bu kez de bir adam ve bir eşek gördüklerini söylemişler ancak bu görüntüler arasında bir bağ kuramamışlardır. Dolasıyla bu görüntülerden anlamlı bir hikaye çıkaramamışlardır. Dahası, Wilson Afrikalı seyircilere göre bir sahnede bir karakterin "gözden kaybolması" için tıpkı gerçek hayatta olduğu gibi, yürümekte olduğu yolu bitirmesi ve köşeyi dönmesi gerektiğini fark etmiştir. Karakter doğal olarak gözden kaybolmadan sahne sonlanıp başka bir sahneye geçildiğinde film seyretme deneyimi olmayan seyirciler, filmin yansıtıldığı perdenin arkasına bakıp karakterin nereye gittiğini görmek istemişlerdir. Buradan hareketle Wilson, filmlerin görülmesi için pek çok sembol barındırdığ $\mathrm{ve}$ bu sembollerin film okuryazarlığı yetisinin kazanılarak anlaşılabileceği sonucuna varmıştır (Ildırar, 2015, s. 62).

Filmler seyirciyi perdeye taşıdıkları evrenler aracılığıyla farklı öyküleri paylaşmaya davet eder. Bu öyküler çok katmanlıdır ve çoğu zaman bu katmanların hepsi görülmemektedir. Ancak filmler buna rağmen tanımlayamadığımız anlamlara ve alt anlamlara dair okumalara izin verir 
(Kabadayı, 2013, s. 11). Farklı öykülerin farklı katmanlarında anlam çıkarmaya çalışan seyirci, filmleri görür ve işitir, onları zihni ve bedeni ile deneyimler. Diğer bir deyişle, film seyirciyi şaşırtır, seyirci şaşırır, film duyguları hareket geçirir, seyirci duygulanır, film bir sahne kurar, seyirci o sahneden takibe başlar, filmin verdiği ip uçlarını aklında tutar, filmler seyirciye bir şeyler yaparken, seyirci de onlarla bir şey yapar (Bordwell, 2013, s. 29).

Albert Laffay'in de söylediği gibi film hem roman hem de figüratif resimler gibi diğer sanatsal yapitlardan çok daha öteye giden nerdeyse gerçek bir gösteriye doğrudan tanık olduğumuz duygusunu yaşatmaktadır. Film tıpkı gerçek hayat gibi devinim içinde ilerler. Öyküsünü oluşturan olaylar tıpkı gerçek yaşama özgü olaylar gibi devingendir. Böylelikle film seyircide algısal ve duygusal bir katılma sürecini harekete geçirmektedir. Zihinsel ve duygusal bu harekete geçiş filme olan inançla ilgilidir. Diğer sanatsal yapıtlarındakinden çok daha güçlü olan bu inanç kimi zaman neredeyse yüz yüze gelinen bir gerçeklik düzeyine erişir ve bize bu böyledir demektedir. Sinema seyircisinin görmek istediği şey de "orada olmuş olan" değil fotoğrafta olduğu gibi, "yaşanan bir orada" olandır (Metz, 2012, s. 19-20). Bazı filmler gerçeğe daha çok benzer görünür, bazıları daha az. Ancak, her filmin öyle ya da böyle gerçekle bir ilişkisi vardır. Eş deyişle, her birinin bir düzeyde mutlaka gerçeklikle, yaşadığımız, tecrübe ettiğimiz, bildiğimiz ya da sadece hayal ettiğimiz gerçeklikle ilgisi vardır (Yaren, 2013, s. 169). Bu noktada kurmaca film en basit ve en temel düzeyde gerçeğin dilsel ve anlamsal olarak yeniden konumlandırılması olarak tanımlanabilir (Bozkurt, 2019, s. 37). Anlatının örtük dilini anlayan ve filme eleştirel yaklaşan bireylerin gerekliliğine işaret eden film okuryazarlığı ise bu bağlamda devreye girmektedir (Medin, 2017, s. 466). Filmlerin irdelenmesinde resim, edebiyat, tiyatro, heykel gibi diğer sanat dalları ile mimari gibi alanlar önem taşır. Aslında yaşamdan beslenen filmleri okumak için insan ve insana dair her şey önemli önemlidir. Bir film okuryazarı, psikolojiden, felsefeye, sosyolojiye, bellek kavramından toplumsal cinsiyete kadar pek çok alanda tartışılan konulara ilişkin araştırma yapmalı, bilgi sahibi olmalıdır (Kabaday1, 2013, s. 33).

\section{Yöntem}

İçinde bulunduğumuz çağda toplumsal farklılıklara ilişkin bilgi ve düşüncelerin yayılması noktasında en önemli araçlardan biri sinemadır. Filmler toplumsal konulara ilişkin fikir yürüten bir alan haline geldikçe, diğer yandan görsel dil kadar öykü aktarımı açısından da zenginleştikçe, toplumsal teori ile sinema arasında eleştirel bir ilişki kurmak kaçınılmaz olur. Sinema güncel toplumsal sorunları dile getirirken, bireylerin en mahrem alanlarına girerek, onların arzularını ve korkularını şekillendirme açısından bariz bir etki alanına sahiptir. Sinema toplumsal incelemeye ilişkin yorumlar üretir, daha önceki kabulleri eğip büker ve yerinden eder. Bu güce sahip sinema toplumla ilgili fikir sunmakla kalmaz, aynı zamanda perdeye aktardığı toplumun ayrılmaz bir parçasıdır (Diken \& Laustsen, s. 23-24). Sosyal, politik ve kültürel açıdan toplumun aynası olarak kabul gören sinema, toplumda yaşanan olayların anlatılması açısından önemli bir aktarım özelliğine sahiptir ve genellikle var olan gerçekliği perdeye yansıtır. İçerik olarak başlangıcından itibaren yaşanan toplumsal olaylara benzer şekilde gelişim gösteren sinema, belirli dönemlerde yaşanan toplumsal değişimleri her zaman perdeye aktarmıştır (Uğur, 2016, s. 917). Gündelik hayata ilişkin birçok önemli konuyu seyirciye sunan sinemanın, seyirciyi olaylardan haberdar ederken, bilgilendirici bir yönü de mevcuttur. Sinema bu yönü ile, toplumun kültüründen etkilendiği gibi toplumu da etkileyendir. Sinemanın bu etkisi, toplumda yaşanan olayları aktarımı açısından sinema ile toplumsal gerçeklik kavramları arasında bir ilişki olduğunu göstermektedir (Güngör, 2017, s. 105).

Filmlerin toplumu resmettiği iddiası, eleştirel sinema çalışmalarına ilişkin yaklaşımların başında gelmiştir. Buna göre, sinema bireysel olan kadar toplumsal olanı da yansıtmaktadır. Ancak sinemada toplumsal olanı eleştirel olarak perdeye taşımak her zaman kolay değildir.Sinema toplumsal olanla ve toplumsal gerçeklik ile ilişkisi bağlamında bir taraftan sanal bir toplumu diğer taraftan gerçek bir toplumu yansıtmaktadır. Diğer bir deyişle, kurmaca dünyada resmedilen toplum 
gerçekte mevcut değilmiş gibi yapılanır. Oysa filmlerle beyaz perdeye yansıyan toplum gerçekte var olan toplumla eş güdümlüdür. Bu nedenle filmin katmanlarında gizlenmiş düşünceleri açığa çıkarmak, birden çok kavramla bağlayarak sosyolojik eleştiri yapmak bir toplumun geçmişini ya da bugününü değerlendirmenin bir aracıdır. Bu noktada, filmleri doğru eleştirebilmek için gizlenmiş kodları doğru kavramlarla doğru açıdan okumayı bilmek gerekir (Karadayı, 2013, s. 54-57). Filmlerin sosyal bilimlere dayalı bir çerçeve içinde sosyolojik ölçütlere göre eleştirilmesini ön gören yaklaşım, filmleri toplumsal bir sanat ve kültür ürünü olarak değerlendirmektedir. Bu açıdan film, yönetmenin kişisel dişavurumundan ya da görsel özelliklerinden çok, üretilmiş olduğu ya da ele aldığı dönemin toplumsal koşulları bağlamında incelenmektedir. Bu bakış açısı ile bir film hangi türe ya da tarihsel döneme ait olursa olsun toplumsal veriler sağlayan bir belge olarak değerlendirilmektedir. Bu anlayış temelinde, sosyolojik eleştiri filmleri sınıf, ırk, cinsiyet, ulus gibi kavramlar ekseninde çözümlemektedir. Bu kavramlar ışı̆ı̆nda sosyolojik yaklaşımla bir filmi okuyan film okuryazarı tıpkı bir sosyolog gibi filmleri toplumun değer yargılarını, kuralların, ideallerini ve dünya görüşünü yansıtan bir kültürel ürün olarak ele almaktadır (Özden, 2004, s. 153154).

Filmleri sosyolojik açıdan okumak; Filmin kültürel ve ulusal niteliği nedir? sorusuna yanıta aramaktır. Bu bağlamda, cevap verilmesi gereken en önemli soru, filmin üretildiği ülkenin kültürüne dair ne söylediğidir. Çünkü, kültürel kodlar ülkeden ülkeye ve kültürden kültüre farklılık gösterir. Film çözümlemesi yapabilmek hem sosyal yapıyı hem de filmleri daha iyi anlayabilmek, ele alınan filmlerle kültür ve kültürün diğer alanları arasında bağlantı kurmayı gerekli kılmaktadır. Ulusal sinema kavramına yönelik tartışmalar da bu yaklaşım içinde yer almaktadır (Corrigan, 2007, s. 19-113). Ünal'a göre; her ülke sineması içinde bulunduğu toplumu yansıtan ayna niteliğindedir. Rus sinemasının temel öyküleri Ekim Devrimi'nden bu yana Rusya'da yaşananlar iken, Birinci Dünya Savaşı'ndan yenik çıkan Almanların sinemasındaki korku, savaş zamanı gölgelerin kol gezdiği sokaklarda yaşanan dehşette gizlidir. Bunun yanında, toplumun neredeyse tümünü etkileyen ve insan zihninde derin izler bırakan savaşlar, kıtlıklar, doğal afetler sinema sanatı için çok değerli kaynaklardır. Yönetmenler, zihinlerinde derin izlerle hayatına devam eden kimseleri en iyi şekilde anlatmayı, seyircinin onlarla empati kurmasını sağlamayı, duygularına hitap etmeyi hedeflemektedirler (Ünal, 2011, s. 25).

Filmleri sosyolojik açıdan okuyan film okuryazarı, filmsel anlatı içinde toplumun en önemli parçası olan insanların birbirlerini, çevrelerini ve toplumu anlamlandırmalarına yardımcı olan ifadeleri tespit ve deşifre etmeyi amaçlamaktadır. Sosyolojik eleştiri filmleri, temalarını ve belirli sınıfsal özellikler arz eden karakterlerini ve rol modelleri çözümleme amacı ile değerlendirmektedir. Sözü edilen konu ve karakterlerin kaynağ 1 toplumsal yaşamdır. Perdede yaratılan evren, toplumsal ilişkiler bağlamında ortaya çıkmaktadır (Akbulut, 2010, s. 268-273). Bununla beraber film hakkında bir değer yargısı yürütmeyen sosyolojik eleştiri tespit yapmakla yetinir, diğer bir deyişle betimleyicidir (Özden, 2004, s. 157). Tarih boyunca "Sinema toplumuтuzu anlamak için nasıl kullanılabilir"? Sorusunu soran pek çok sosyolog tüm öznelerin sosyal çerçevede hareket ettiğini varsaymaktadır. Bu bağlamda, filmlerin bize toplumdaki yaşama ilişkin mutlaka bir şeyler söyleyeceğini düşünmektedirler. Sinema topluma ve toplumsal sürece ilişkin veriler sağlayabilir. Diğer yandan, filmler toplumdaki hegemonik düşünce ve yapılara, mevcut stereotiplere, basma kalıp yargılara, ahlaki değerlere, ideolojilere karşıt bir tavır sergiler ya da onaylar. Dolayısıyla filmler sosyolojik bakış açısı ile değerlendirildiğinde, değerlendirilen bir film değil, bir sanat eserinin topluma bakan "sosyal boyutu"dur (Nasciment, 2019).

$\mathrm{Bu}$ çalışmada $\mathrm{K} ı z$ Kardeşler (Alper, 2019) filmi sınıf, toplumsal cinsiyet, rol ve iktidar bağlamında sosyolojik açıdan analiz edilecektir. Filmin seçilmesinin sebebi, ülkemizde belirli bölgelerde görülen besleme olgusunu, toplumun tümünü ilgilendiren toplumsal cinsiyet ve sinıf çatışmaları üzerinden anlatmış olmasıdır. "Yetiştiğim kasabada besleme çok yaygın bir uygulama idi. Arkadaşlarım vardl. Köyden gelmiş evlatlık edinilmiş kızların durumu beni çok üzerdi. Hem aileden koparılmış olmaları hem de yani ailelerine tam olarak ait olamamaları, kabul edilmemeleri 


benim için bir dertti. Bu klzların hikayelerini anlatmak istedim"

(https://www.youtube.com/watch?v, =_t7FDDprYwQ, 2020).

Filmin öyküsünün içinde yaşadığı toplumdan izler taşıdığını ve bu doğrultuda filmde toplumsal kesitler sunulduğunu belirten yönetmen, karakterleri bildiği ve tanıdığ 1 insanlardan seçtiğini dile getirmektedir (https://www.youtube.com/watch? v=AUOUXvnEMSY, 2020).

\section{Bulgular ve Tartışma}

\subsection{Sınıf Kavramı ve Sınıf Mücadelesi}

Sarp kayalıklarla çevrili köye doğru ilerleyen bir araba ve bu arabanın arka koltuğunda ağlayan bir kız sahnesi ile başlayan film, besleme olarak kasabaya giden ve geri dönen üç kız kardeşin köyden çıkma çabasını anlatır. Filmde yer alan zıtlıklar hem sınıf mücadelesi hem de toplumsal cinsiyet bağlamında değerlendirilebilir. Üç kı kardeşin var olma mücadelesinin anlatıldığı filmde öncelikle şehirli ve köylü olarak ta kategorize edilebilecek taşralı ve kasabalı zıtlığı, eş deyişle sınıfsal bir ayrım göze çarpmaktadır. Sınıf kavramı en temelde ortak özellikleri olan bir grup insan olarak tanımlanabilir. Sınıflar arası fark ise sosyal sınıfların farklı eğitim, statü, gelir, iş, meslek ve yaşam biçimleri ile çocuk yetiştirme şekilleri ve değerlerinden yola çıkarak saptanır (Uğur, 2016, s. 919). Doktorluk yapan Necati kasabalı temsili iken çobanlık yapan Veysel taşralıdır. Bu ikili arasındaki zıtlık sınıf mücadelesinin en bariz örneğidir. Modernliğin temsili olan Necati, aynı zamanda bir güç unsurudur. Köyden çıkmayı, kasabada yaşamayı, doktor olmayı başarmış bir güç figürüdür (Çavaş, 2020, s. 56). Necati, köyde bu kadar saygı duyulan bir figür iken öte yandan, çobanlık yapan Veysel bir o kadar hor ve küçük görülen bir karakterdir. Veysel'in varlığı ile yokluğu ev halkı içinde önemsizdir. Gökhan'ın hastaneye götürüleceğini öğrendiğinde neden ona söylenmediğini sorduğu sahne ev halkı tarafından önemsenmediğini gözler önüne sermektedir.

Veysel: Gökhan'ı hastaneye götürecekmişsiniz.

Reyhan: Ne var, ishal çocuk kaç gündür.

Veysel: Hiç hasta gibi değil. Gülüyor, oynuyor.

Reyhan: Benden iyi mi bileceksin? Ben değiştiriyorum altını, cıvık çıkıyor kaç gündür.

Veysel: Geçen ay zatürreden geberiyordum burada, ama kılınız kıpırdamıyordu hiç.

Şevket: El kadar bebekle mi klyasllyorsun lan kendini?

Öte yandan, ev halkı tarafından Veysel'in aldığı hiçbir karar da ciddiye alınmaz. Örneğin Veysel, gece yanına eşkıyaların yanaştığını artık sürüye gitmek istemediğini dile getirir. Şevket gülerek Veysel'in gölgesinden korktuğunu, babasının da böyle olduğunu söyler bunun üzerine kızlar da gülerler. Reyhan "baba uğraşma yarım akilliyla" der. Veysel sadece ev halkı tarafindan değil, içinde bulunduğu toplum tarafindan da dişlanmakta, eş deyişle önemsenmemektedir. Sınıfların oluşturduğu toplum kavramını tanımlamadan önce toplumun ne olmadığına bakmak gerekir. Toplum sadece onu oluşturan bireylerin matematiksel toplamı değildir. Bireylerin kendilerine özgü bireysel özellikleri birbirlerinden farklı olduğu kadar, bir arada yaşayan bireylerin nitelikleri, özellikleri de başkadır. Diğer bir deyişle, birey bir toplumun üyesi olduğu zaman nitelik değişir. Toplumun bir parçası olarak ondan etkilen birey, toplumdan soyutlanmış, tek başına bir kişinin niteliklerine sahip değildir. Örneğin; bir adada tek başına yaşayan Robenson ile bir toplum içinde yaşayan Robenson aynı varlıklar değildir. Toplumu sosyo kültürel olarak tanımlarsak, ortak bir çevrede yaşayan belirli değer ve kurallara sahip olan ve birbirleriyle yaptıkları etkileşimlerde bu değer ve kuralları kullanan bilinçli kişi ve gruplardır. Marx toplumu, uzlaşmaz sınıfların çatışmaları sonunda belirlenen bir etkileşim süreci olarak değerlendirir. Toplumda meydana gelen olaylar, farklı sınıfların etkileşimleri dolasıyla ortaya çıkan çatışmalardır (Kongar, 2012, s. 41-45). 
Necati'nin isteği üzerine Şevket ve muhtar bir sofra hazırlatır. Bir ara Veysel yanlarına gelir, Şevket ve muhtar Veysel'in gelmesinden rahatsız olurlar. Veysel Necati'den iş ister.

Şevket: Kim bakıyorsun ulan iş, kendine mi?

Ulan okumast yazması olmayan adamın doktor muayenehanesinde ne işi olur?

Necati: Bak şimdi, ne enteresan. Sen kasabaya özeniyorsun. Ben de sana özeniyorum.

Muhtar: Estağfurullah

Şevket: Estağfurullah

Necati: Tabii ya, bak mesela imkânım olsa diyeceğim ki ver koyunları bana, çıkayım dağa, vallahi. Karışan yok, görüşen yok, mis gibi hava.

Veysel Reyhan ve Gökhan ile kasabada yeni bir yaşam sürmek için Necati'den iş isterken, Şevket Veysel'in okuma yazma bilmemesini dile getirerek, onun kasabada çalışmak için gereken asgari özelliğe bile sahip olmadığını küçümser bir tavırla dile getirir. Veysel'in kasabada yeni bir hayat kurmayı hayal etmeye dahi hakkı yoktur. Öte yandan, Necati'nin Veysel'e özendiğini ifade etmesinin ardından Şevket ve muhtar, "olur mu öyle şey" anlamında "Estağfurullah" derler. Diğer bir deyişle, Necati'nin Veysel gibi birine özenmesi mümkün değildir. Sahnenin devamında, Veysel' in iş konusunda 1srarını sürdürmesi Necati'yi rahatsız eder: "Hayır bir de siz şehre gelmeyi kolay bir şey zannediyorsunuz. Çünkü herkes orada hazır bekliyor gelsinler diye. Kardeşim, senin bir mesleğin var mı? Yok. Birikmiş paran var mi? Yok. Okuman yazman yok be. Geleceksin burada, armut piş ăgzıma düş, oh”.

Necati, daha güzel bir hayat yaşamak için kasabaya gidip çalışmak isteyen Veysel'e ait olduğu sınıfa ilişkin yetersizliklerini sıralar, bu halde kasabaya gitmesi mümkün değildir. Öte yandan, sınıfı tanımlarken sadece ekonomik düzey, mesleki alan, eğitim düzeyi gibi toplumsal yapıyı ve hiyerarşiyi dikkate almak yeterli değildir. Daha bütüncül bir bakış açısı ile sınıf, her birini önceleyen ve belirleyen hepsinden farklı, hepsinin üzerinde yer alan bir olgudur. Sinıf gerçekliği, toplumsal düzen üzerinde doğrudan ya da dolaylı olarak etkide bulunan, ekonomik, sosyal, siyasal eşitsizliklerin, güç ilişkilerinin ve bu ilişkilerin büründüğü tüm biçimlerin temelini oluşturan, kısaca çok yönlü bir etmendir (Öngen, 2006, s. 25). Köyde Necati'ye sonsuz bir sayg1 duyulur. Yaptığı her şey, aldığı her karar sorgulanmadan onanmaktadır.

Necati: Siyaset bize göre değil be muhtar.

Muhtar: Tabii abi, siyasetçi dediğin adam azıcık üçkâğıtçı olacak.

Şevket: Senin gibi namuslu, dürüst adamın ne işi olur siyaset ile?

Öte yandan, köyde Gökhan'ın Reyhan ve Necati'nin çocuklan olduğuna ilişkin dedikodular yayılmıştır. Necati ve Şevket arasında bu mesele hiç konuşulmaz. Veysel köyde böyle dedikoduların döndügünü Necati'ye söyleyince Necati çıldırır ve Veysel'e saldırır. Bunun üzerine Şevket: “...ne yapacaksın, bu Veysel böyle yarım akıllıdır. Lafina falan da kimse kulak asmaz onun. Kimse hesaba katmaz onu köyde" der. Veysel yine kimsenin sözüne itibar etmediği yarım akıllı olarak yaftalanır. Güç unsuru Necati’yi rahatsız edecek her şeyin üzeri örtülür.

Sınıf gerçekliğinin filme yansıdığı bir başka nokta besleme uygulamasıdır. Besleme olarak kasabaya giden kızlar bir taraftan yeni ailelerine tam anlamı ile dahil olamamakta diğer taraftan köye, kendi ailelerinin yanına dönmekten rahatsız olmaktadırlar.

Nurhan: Ben kendi kendimi hasta ettim.

Dedim ki...Ben belki hasta olursam...

Belki bana acırlar da çamaşırlarını yıkatmazlar dedim. 


\section{Belki dedim, çocuklarının kulağını çekerler. Ama onlar beni bu köşeye attılar.}

Kızlar besleme olarak gönderildikleri ailenin ebeveynlerine anne ve baba diye hitap ederler, ancak hiçbir zaman o evin gerçek kızları gibi muamele görmemekteler. Ev işi yapan, çocuk bakan, yemek yapan kızların hizmet ettikleri ailelerin onlara hizmetçi gibi davranmalarına rağmen, o evlere geri dönmek istemeleri, filmdeki arada kalmışlığın, zıtlığın bir göstergesidir. Nurhan, Necati Bey ve Neriman ona daha iyi davransınlar, daha fazla çamaşır yıkamak zorunda kalmasın diye bilerek kendini hasta eder. Ancak beklediği sonucu elde edemez. Arada öksürüyor olmas1 kimsenin dikkatini çekmemiştir ve Özgür'e sert davranması sebebiyle köye geri getirilir. Nurhan köye gelir gelmez yaptıklarına pişman olur ve Necati Bey'e onu geri götürmesi için yalvarır. Necati Bey'in evine besleme olarak gönderilme ihtimali olan Havva'nın çantası ise hep hazırdır. Köy kurtulmak istenen yer iken, hizmetçilik yapacaklarını bilseler de kızlar için kasaba kurtuluştur.

İnsanların dünyada yaşadıkları yer ve yaşadıkları yerde gerçekleştirdiği eylemler, onların yaşadıkları ortalama yaşam süreleri ve mevcut seçeneklerini ve fırsatlarını büyük ölçüde etkiler. Öte yandan, tanımlı bir bölge veya halk içindeki kıt kaynaklara sahip bir bireyin konut, eğitim, evlenecek kişi için rekabet eden bir bireyin, ötekilere kıyasla gelir, mülkiyet, güç ve statü bakımından nasıl konumlandığı sorusu da eşit derecede önem taşır (Jarvis vd., 2012, s. 117). Yoksulluğun sadece gelir yokluğu ya da düşük tüketim düzeyi aracıllğıyla işlevini yerine getirmekle sınırlandırmak doğru değildir. Aynı zamanda yoksulluk barınma, gelir, tüketim, söz hakkı, temel hizmetler, haklar, yönetişim gibi çoklu yoksunlukla ilişkili ve çok boyutludur (Sen, 1999). Havva köye geri döndükten sonra, onunla aynı mekanda uyumak istemeyen Veysel Şevket'e Reyhanla evli olduklarını bu yüzden Havva ile aynı odada yatmak istemediğini söyler, bunun üzerine Şevket: "Mahremine o kadar düşü̈nsen git kendine ev yaptır" der. Sosyo- ekonomik durumu güçlü olmayan dolasıyla iktidar unsuru olmayan Veysel, nerede yaşayacağı, nerede uyuyacağına ilişkin konuşma ya da tercih hakkına sahip değildir.

\section{2.İktidar Bağlamında Toplumsal Cinsiyet ve Roller}

Toplumsal cinsiyet rolleri arasındaki bütün ilişkiler esasında bir iktidar mücadelesidir. Cornell'e göre erkeklerle kadınlar arasındaki toplumsal cinsiyet düzeni, geçmişten günümüze kadınlık tanımıyla erkeklik tanımı arasında kurulmuş güç ve iktidar ilişkileri örüntüsüdür (Cornell, 2016, s. 140). İktidarda olan gücü elinde bulunduran erkektir. Öte yandan, gücü elinde bulunduran erkekler oldukları farklı iktidar biçimleri ile sadece kadınlar üzerinde değil, diğer erkekler üzerinde de iktidar kurarlar ve varlıklarını kurdukları bu iktidar içinde sürdürürler. Ana erklilikten ataerkilliğe geçiş sürecinden sonra, iktidara sahip olan erkeğin, tarihsel süreç içinde bu gücünü koruyarak, iktidara sahip olmasını sağlayan sistem, kendi kimliğinin oluşumunda da belirleyici olmuştur. Erkek egemen sistem, tıpkı kadına yüklediği roller gibi erkeğe de cesaret, ciddiyet, güçlü olmak, evine, ailesine bakmak, çalışmak gibi toplumda kabul görmüş, geçerli erkeklik normlarına uygun davranması gerektiğini öğreterek, erkeklik rollerini sürekli kılmıştır (Segal, 1992, s. 161). Toplumsal cinsiyet alanı tamamen güç, eşitsizlik ve şiddet içerir. Filmin erkekleri ne kadar acınası, sevimsiz, beceriksiz ve iktidarsız olursa olsun kız kardeşler, onların iktidarında hapis kalmış durumdadırlar (www.alt yazi.net, 2021). Havva ve Nurhan'1 köye geri getiren erkeklerdir, onları geri götürecek olan yine erkeklerdir. Reyhan ise Necati Bey'in evinden ayrılmak zorunda kalınca köye dönmek yerine Ankara' ya teyzesinin yanına gitmek ister ama babası izin vermez ve onu köye getirir. Eş deyişle, kadınların geleceklerine karar veren erkeklerdir. Şevket kızlarının bir şekilde kasabaya besleme olarak gitmesi için elinden geleni yapar. Reyhan geri dönmek zorunda kalınca, Necati Bey'in evine Nurhan'1 gönderir. Nurhan geri getirilince de Havva'yı göndermek için Necati Bey'i ikna etmeye çalışır. Şevket'in çabası kızlarının besleme olması iken, kasabaya gitmelerini sağlayacak yine bir erkektir. Sadece kız kardeşler içinde değil babaları için de kızların köyden kurtulup yeni bir hayat sürmelerinin yegane yolu Necati'dir. Havva'nın besleme olarak kasabaya gitmesi, Nurhan'ın iyileşmesi, Reyhan'ın Ankara'ya gitmesi için Necati'nin kasabaya gelmesi gerekmektedir. Kız kardeşlerin köyden kurtulmalarının yolu Necati’ye bağlıdır. 
Toplumsal cinsiyetçiliğe göre çekirdek aile ve ailenin iyi bir arada tutulması önemlidir. "Aile" ve "cinsiyet rolü" nü bir bütün olarak ele alan sosyolojik çalışmaların asıl odağ anne olarak kadınlar eş deyişle kadınlık rolüdür. Cinsiyet farklılığına ve toplumsal cinsiyete ilişkin ortak bir rol kavramının çıktığı nokta ise cinsiyet rolüdür. Kişinin cinsiyeti ile belirlenen genel bir rolün canlandırılması erkek veya kadın olmanın anlamıdır. Buna göre, kadınlığı ve erkekliği ilgilendiren herhangi bir durumda "Erkek rolü" ve "kadın rolü" olmak üzere iki cinsiyet rolü vardır (Cornell, 2016, s. 85-63). Rol; "bir işte bir kimse veya şeyin üstüne düşen görev" olarak tanımlanır (www.sozluk.gov.tr, 2021). Film boyunca kadınlar toplumsal cinsiyetçiliğin kadınlara biçtiği yemek hazırlama, temizlik yapma rollerini yerine getirirlerken görülmektedirler. Kadınlar sadece ev içinde ya da etrafında hizmet etmekle kalmaz, Necati, Şevket ve muhtarın kayalıklarda kurduğu yemek sofrasında hizmete eden Havva, yine bir kadındır. Besleme olarak Necati'nin evine gönderilen Reyhan toplumun ona biçtiği rollerin dışına çıkınca cezasını köye geri getirilerek çoban Veysel'le evlenmekle öder. Öte yandan, Necati hayatına devam eder.

Diğer yandan, her ne kadar filmin kadınların geleceği erkekler tarafından belirlense de ya da toplumsal cinsiyetçilik bağlamında kadınlara biçilen roller gereği yemek, temizlik, ev işleri yapsalar da kadınlık rolleri bilindik basmakalıp temsillerden farklıdır. Üç kız kardeş de kendilerini rahatlıkla ifade edebilmekte, dahası babalarıyla mizahi bir dille dalga geçmektedirler.

Şevket: Muhtar, kime gelir akıl danışmaya? Bana gelir, bana.

Reyhan: Ay anam, baba başladin yine kendini övmeye.

Şevket: Ne yapayım, kimse övmeyince mecburen ben de kendi kendimi överim.

Reyhan: Allah aşkına baba, biz senin nereni öveceğiz?

Kızlar her ne kadar fikirlerini dile getiriyor olsalar da düşünce dünyaları yine var oldukları toplumla paralellik göstermektedir. Veysel ve babaları ile diledikleri gibi konuşan ve onlara diledikleri gibi davranan kız kardeşler Necati gibi iktidar sahibi erkeklerle konuşurken daha çekingen, ihtiyatlı ve saygılı davranmaktadırlar. Buna göre ataerkil toplumda, ailenin geçimini sağlayan erkektir. Erkek eğer ailenin geçimini sağlayabiliyorsa, kamusal alandaki iktidar düzeninin, mikrosunu evde kurmuş olur. Dolasıyla, ekonomik gücü elinde bulunduran erkek ailenin karar merciidir (Poole,1993, s. 74). Erkeğin kendisine yüklenen bu rollerin dışına çıkması ise, birtakım yaptırımları karşılayacak güç ve istekle olmasıyla doğru orantılıdır. Çünkü sistem tarafından kabul gören rollerin dışına çıkan erkek, farklı tanımlarla yaftalanarak kılıbık, soğan erkeği sıfatlarla alay edilir ve küçümsenir. Reyhan Veysel'in Necati Bey'le tartıştı̆̆ını öğrendiğinde Veysel'e çıkışır. "Leş gibi de rakı kokuyorsun. Cinsi bozuk! Sen ne bilirsin rakı içmeyi falan? Kendini rezil ettin mi orada millete? Ayıp! Utan, utan! Necati Bey'in yanında. Insan kendini, hiç olmadı bir yerini bilir be! Bana sormadan sen neler karıştırlyorsun yarım aklınla?" Film boyunca Veysel'den bahsederken ya da Veysel'e karşı "yarım akıllı, deyyus, uğursuz, deli, korkak, divane, meczup" gibi olumsuz sıfatlar ve küfür ifadelerinin kullanıldığ 1 görülmektedir. İktidara sahip olmayan Veysel her alanda yok sayılmaktadır. İktidar;

1. Bir işi yapabilme gücü, erk, kudret:

2. Bir işi başarabilme yetki ve yeteneği.

3. Devlet yönetimini elinde bulundurma ve devlet gücünü kullanma yetkisi:

4. $\mathrm{Bu}$ yetkiyi elinde bulunduran kişi ve kuruluşlar (www.sozluk.gov.tr, 2021) anlamlarına gelmektedir. Bu tanımlardan da anlaşılacağı gibi, oldukça geniş bir alanda kullanım bulan iktidar sözcüğü bir güç kavramı içermektedir. Erkek kimliğinin oluşumundaki faktörlerin başında gelen iktidar aynı zamanda erkeğin güç alanıdır. Erkek bu gücü hem kadın hem de diğer erkekler üzerinde kullanmaktadır. İnsana özgü ve insanlar arası bütün ilişkilerde kendini gösterir (Foucault, 2014, s. 235). İktidara sahip olan her alana müdahale etme gücünü kendinde 
bulmaktadır. Necati, köyden çıkmayı başarmış, doktor olmuş, aynı zamanda kasabada benzin istasyonu olan, köyde arazisi olan bir güç unsuru olarak kontrolü elinde tutan ve tutmak isteyen iktidarı temsil etmektedir. Kontrol hep kendinde olsun ister. Örneğin; Veysel Necati’ye kasabada Reyhan'ın Necati'den hamile kaldığı dedikodularının konuşulduğunu söyleyince Necati çıldırır. Bu yapısal olgu, toplumda hegemonik erkeklik kavramını tanımlayan erkeklerin arasındaki ilişkilerin temelidir. Hegemonik erkeklik sadece kadınlarla ilgili değil, aynı zamanda dışlanmış, ikincil konuma itilmiş vb. erkeklik biçimleriyle de ilgilidir. Ataerkil bir toplumsal düzenin işleyiş biçiminin ayrılmaz parçası da bu erkeklik biçimleri arasındaki etkileşimdir. Hegemonik erkeklik kavramındaki "hegemonya”, Gramsci'nin İtalya'daki sınıf ilişkilerini değerlendirirken bahsettiği gibi, acımasız iktidar çekişmelerinin ötesinde özel yaşama ve kültürel süreçlerin örgütlenmesine sızan bir toplumsal güçler oyunun sonunda kazanılan, toplumsal üstünlüktür. Hegemonya, erkeklerden oluşan bir grubunun, silah zoru veya ekonomik olarak zorda bırakma tehdidi ile başka bir grup üzerinde kurduğu üstünlük değildir (Cornell, 2019, s. 268). Erkekler şartları ve konumları gereği nedeniyle iktidar alanıyla doğrudan ilişkilidir (Cornell, 2019, s. 21). Necati sadece kadınların kurtuluşlarının anahtarı değil aynı zamanda filmin erkeklerinin de önündeki bir güç figürüdür. Havva'nın kasabaya gitmesi için Şevket Necati'yi ikna etmelidir. Buna kadar verecek iktidar sahibi Necati'dir. Şevket hiçbir zaman kızlarının dönme sebebinin üzerinde durup onlarla konuşmaz, eğer Necati kızları geri getirdi ise kızlar koşulsuz suçludur. İktidar bir karar vermiştir ve bu sorgulanmaz. Şevket ve Necati arasındaki diyaloglarda Şevket'in Necati'yi hep olumladığı ve övdüğü görülür. Bu bağlamda ataerkil toplumsal yapının erkekliğe verdiği ayrıcalıklar ve böylece elde edilen iktidarın verdiği hegemonik üstünlük kendisini erkeklik biçimlerinde gösterir. Erkeklik kavramı kadınlar ve diğer erkeklerle ilişkili bir yapı olması sebebiyle değişen sosyoekonomik koşullara ve kadınların toplumdaki konumlarına göre yeniden tanımlanıp yapılandırılmaktadır (Kimmel, 1987, s. 212). Erkeklerin işsizliği ya da işlerini kaybetmeyi sosyal hayatlarındaki değer ya da iktidar kaybı şeklinde değerlendirmesinin sebebi budur (Uçan, 2012, s. 266). Erkeklik, toplumsal olarak iktidar temelinde kurulan cinsiyet düzeninin ve buna bağlı üretilen kültürel, ideolojik, dilsel, siyasal devamlılığ temsil eden bir toplumsal cinsiyet biçimdir. Bu biçim günümüzde yaşanılan kültürel iklimin etkisi altında kendisine biçilen rolleri üstlenerek "erkeklik" hallerine sokulur. Öyleyse günümüzdeki erkeklik kalıbı neyi ifade eder? Günümüz toplumunun pek çoğunda erkeklik algısi; baskıcı, sert, saldırgan, şiddet tutkunu, öfkeli ve güçlü bedene sahip bireyi içermektedir (Kara, 2021, s. 192). Erkekliğin, kadınların mücadeleleri ile kazandıkları haklar, çalışma hayatı, söz hakkı edinme, kendini ifade erme gücünün artması gibi yaşamsal alanlarda gelişen değişimler sonucunda sorgulanması ile geleneksel pozisyonlardan "yeni" ve "belirsiz" pozisyonlara geçtiği görülmektedir. Fiziksel, duygusal ve psikolojik aşamalarda görülebilen bu erkeklik krizlerinin Türkiye'de de tartışılan toplumsal ve bireysel yansımalarını (Sevim, 2019, s. 27) filmde de görmek mümkündür. Filmin iktidar eş deyişle otorite figürü Necati’ye tek karşı çıan Veysel'dir, ama her defasında ya dayak yer ya da hırpalanır. İktidar olmanın koşullarından meslek ve maddi durum ekseninde Necati'nin çok gerisinde olan Veysel Reyhan'1 köyün dilinden kurtarsa da Gökhan ve Reyhan için kasabaya gitmek, yeni bir yaşam kurmak istese de ona saygı duyulmaz. İntihar etmeden önce "Keşke beni hor görmeseydin. Keşke beni hor görmeseydiniz" sözleri toplumun ona yaklaşımını özetler.

\section{Sonuç}

Öykülerini çoğu zaman gerçek hayattan alan sinema, içinde yaşadığımız toplumu, anlamanın ve anlamlandırmanın yollarından biridir. $\mathrm{Bu}$ tür filmler üretilmiş oldukları ya da ele aldıkları dönemin toplumsal verilerine göndermede bulunur. Bu bağlamda sosyolojik analiz ile çözümlenen fillmler toplumun değer yargılarını ve ideallerini yansıtan kültürel bir ürün olarak görülür. Filmleri sosyolojik anlayışla okumanın temelinde ulus, sınıf, ırk, cinsiyet çerçevesinde toplumun değer yargılarını, toplumsal hafizasını, yaşam biçimini, toplumsal rolleri saptamak hedeflenir. Bu bağlamda incelenen, Klz Kardeşler (2019) filminde yönetmen, sınıf çatışmaları, iktidar ve toplumsal cinsiyetcilik ekseninde sıkışıp kalan üç kızkardeşin öyküsünü kendi 
geçmişinden gözlemlerle sosyolojik okumaya elverişli bir şekilde aktarmaktadır. Filmde sınıf çatışmaları, iktidar ve toplumsal cinsiyet alanına sıkışarak mücadele veren sadece kadınlar değlidir. İkidara sahip olan yalnızca kadınlar üzerinde değil, alt sınıftaki erkekler üzerinde de güç sahibidir. Karar mercii olan iktidarın hem kadınlar hem de erkekler için yegane kurtuluş seçeneği olduğu görülmektedir.

\section{Kaynakça}

Bordwell, D. (2013). The viewer's share: models of mind in explaining film. İçinde A. Shimamura (Ed.), Psychocinematics: exploring cognition at the movies, ss. 29-53. Oxford University.

Bozkurt, M. (2019). Çıplak objektif kördür: kötünün / çirkinin estetiği bağlamında NBC sinemas1 ve Ahlat Ağacı.İçinde Ş. Sim (Ed.), Filmlerle düşünmek, s.37-52. Kriter Yayınevi.

Büker, S. (2012). Sinemada anlam yaratma. Hayalperest Yayınevi.

Cornell, R.W. (2016). Toplumsal cinsiyet ve iktidar. (Çev.Soydemir, C). Ayrıntı Yayıncılık.

Corrigan, T. (2007). Film eleştirisi. (Çev.Gürata, A). Dipnot Yayınları.

Çavaş, H. (2020). Shadowy events, unreliable narrators, anonymous spaces: seeking ambiguity in Emin Alper's film. [Yayımlanmamış yüksek lisans tezi]. Bahçeşehir Üniversitesi Sosyal Bilimler Enstitüsü.

Diken, B. ve Laustsen, C. B. (2010). Filmlerle sosyoloji. Metis Yayınc1lı.

Foucault, M. (2014). Özne ve iktidar. (Çev. Ergüden, I. ve Akınbay, O.). Ayrıntı Yayınları.

Güngör, E. (2017). 1950'ler Türkiye'sinde modernleşme ve gündelik hayat değişimlerine sinema üzerinden bakmak: İstanbul geceleri. Abant Kültürel Araştırmalar Dergisi, 2(3), 94-112.

Ildırar, S. (2015). Film okuryazarlığı: bir görsel iletişim sistemi olarak devamlılık sineması. Sinecine Sinema Araştırmalarl Dergisi, 6 (1),57-89. https: doi.org/10.32001/sinecine.540272

Jarvis, H., Kantor \& P, Cloke. (2012). Kent ve toplumsal cinsiyet. (Çev.Temurtürkan, Y). Dipnot Yayınları.

Kabadayı, L. (2013). Film eleştirisi: kuramsal çerçeve ve sinemamızdan örnek çözümlemeler. Ayrıntı Yayınları.

Kara, O. (2021). Hegemonik erkeklik iktidarının her yerdeliği: Kelebekler ve Bizi Hatırla. Moment Dergi, 8(1), 188-204. https://doi.org/10.17572/mj2021.1.188204

Kırel, S. (2010). Kültürel çalışmalar ve sinema. Kırmızı Kedi Yayınları.

Kimmel, M. S. (1987). Men's responses to feminism at the turn of the century. Gender \& Society, 1(3), 261-283.

Kongar, E. (2012). Toplumsal değişme kuramlart ve Türkiye gerçeği. Remzi Kitabevi.

Kurudayığlu, Y \& Tüzel, A. (2010). 21. yüzyıl okuryazarlık türleri, değişen metin algısı ve Türkçe eğitimi. Türklük Bilimi Araştırmalarl, (28), 283-298.

Lewis, J \& Jhally, S. (1998). The struggle over media literacy. Journal of Communication, 48 (1), 109-120. https://doi.org/10.1111/j.1460-2466.1998.tb02741.x

Medin, B. (2017). İnsanbiçimci kahramanların dünyasında sinema okuryazarı olmak. TRT Akademi, 2 (4), 466-485. 
Metz, C. (2012). Sinemada anlam üstüne denemeler. (Çev.Adanır, O.). Hayalperest Yayınevi.

Nascimento, J. (2019). Art, cinema and society: sociological perspectives. Global Journal of Human-SocialScience Research, 19 (3),1-11.

Öngen, T. (2006), Marksist sınıf kavramının ve sınıf analizinin ayırt edici özellikleri. İçinde, Tüsam kolektifi, Türkiye'yi sınıf gerçekliğiyle anlamak, 23-31. Ezgi Matbaası.

Özden Z. (2004). Film eleştirisi: film eleştirisinde temel yaklaşımlar ve tür filmi eleştirisi. İmge Kitabevi.

Poole, R. (1993). Ahlak ve modernlik. Ayrıntı Yayınları.

Savaş, H. (2003). Sinema ve varoluşçuluk. Altıkırkbeş Yayın.

Segal, S. (1992). Ağır çekim, değişen erkeklikler, değişen erkekler. Ayrıntı Yayınları.

Uğur, U. (2016). Gurbet Kuşları filmi örneğinde iç göç olgusunun sosyolojik açıdan incelenmesi. Ordu Üniversitesi Sosyal Bilimler Enstitüsü Sosyal Bilimler Araştırmaları Dergisi, 6 (3), 917-926. DOI: 26332/285467

Sen, A. (1999). Development as freedom. Oxford University Press.

Sevim, E. (2019,5-7 Eylül). Erkek (lik)lerin krizlerini izlerken: taşraya 'Uzak' tan bakan erkekler ile 'Ahlat A Ğacı'nın altında yaşayan erkekler arasında betimleyici bir karşılaştırma denemesi. 14. Karaburun Bilim Kongresinde Sunulan Bildiri. Karaburun Gündelik Yaşam Bilim ve Kültür Derneği.

Tuncel, G. (2016). Sosyal bilgiler öğretmen adaylarının sinema filmleri aracıllı̆ıyla felsefi düşünme edimleri. The Journal of Academic Social Sciences, 1 (37), 327-347. DOI: 10.16992/ASOS.1182

Uçan, G. (2012). Post-modern erkek(lik). Manisa Celal Bayar Üniversitesi Sosyal Bilimler Dergisi, 10 (2), 262-271.

Ünal, G.T. (2010). Sinemada estetik kaygı ve anlatım aracı olarak sinema tekniği. İçinde İri, M (Ed.). Sinema araştırmaları: Sinema araştırmaları, kuramlar, kavramlar yaklaşımlar, s.1127. Derin yayınları.

Yalsızuçanlar, S. (2008). Dünyanın orta yeri sinema. Etkileşim Yayınları.

Yaren, Ö. (2013). Sinemada anlatı kuramı. İçinde Özarslan, Z. (Ed.). Sinema kuramları-2: Sinemayl aydinlatan kuramlar, s.167-192. Su Yayınlar1.

\section{Diğer Kaynaklar}

Alper, E. (Yönetmen). (2019). Kız Kardeşler [Film]. Türkiye, Almanya, Hollanda, Yunanistan: Liman Film, Nu Look Production, Komplizen Film, Circe Films, Horsefly Productions.

Alt Yazı- Kız Kardeşler Sonsuz Bir Döngü (2019). https://altyazi.net/yazilar/elestiriler/kizkardesler-bir-sonsuz- dongu/

https://sozluk.gov.tr/ (2021, Haziran 22).

Sinema +. (10 Mart 2020). Emin Alper EYou Tube Kanal1] https://www.youtube.com/watch?v= t7FDDprYwQ-EminAlperSinema+29.Bölüm

BantMag (12 Mart 2020). [BantMag. Soruyor, Emin Alper Cevapliyor] https://www.youtube.com/watch?v=AU0UXvnEMSY 